\title{
PERILAKU HIDUP BERSIH DAN SEHAT PADA IBU HAMIL DENGAN ANEMIA DI WILAYAH KERJA PUSKESMAS IMOGIRI I KABUPATEN BANTUL YOGYAKARTA
}

\author{
Eni Purwaningsih*, Widyawati**, Akhmadi** \\ *Mahasiswa Program Studi Magister Keperawatan Fakultas Kedokteran \\ Universitas Gadjah Mada, Yogyakarta \\ ** Program Studi Magister Keperawatan Fakultas Kedokteran \\ Universitas Gadjah Mada, Yogyakarta \\ Email: enicubung@yahoo.com
}

\begin{abstract}
Latar Belakang: Ibu hamil yang berada dalam rumah tangga yang melakukan perilaku hidup bersih dan sehat (PHBS) akan menurunkan kejadian penyakit yang memperburuk kematian ibu hamil, mengingat bahwa ibu hamil sebenarnya merupakan kelompok yang rentan terhadap resiko sehingga memerlukan suatu lingkungan keluarga/rumah tangga yang mempunyai perilaku hidup bersih dan sehat (Astuti, 2011). Tujuan: untuk mendapatkan gambaran secara mendalam tentang perilaku hidup bersih dan sehat pada ibu hamil dengan anemia di wilayah kerja Puskesmas Imogiri I Bantul Yogyakarta. Metode: Penelitian ini menggunakan pendekatan penelitian kualitatif dengan desain fenomenologi. Teknik pengambilan sampel menggunakan teknik purposive sampling. Pengumpulan data dengan wawancara mendalam pada 6 ibu hamil anemia di wilayah kerja Puskesmas Imogiri I Bantul Yogyakarta. Penelitian ini dilakukan pada bulan Mei sampai September 2014. Teknik analisis data yang digunakan dalam penelitian ini menggunakan teknik analisis Colaizzi. Hasil: Empat tema yang ditemukan pada penelitian ini yaitu ketidakadekuatan perilaku memeriksakan kehamilan/kunjungan antenatal care (ANC), ketidakpatuhan mengkonsumsi tablet besi (Fe), kuatnya kebiasaan mengkonsumsi teh, dan ketidakadekuatan perilaku hidup bersih dan sehat (terkait dengan anemia). Simpulan: Gambaran tentang perilaku hidup bersih dan sehat pada ibu hamil dengan anemia di wilayah kerja Puskesmas Imogiri I Kabupaten Bantul Yogyakarta dapat dilihat dari empat temuan penting dari penelitian ini yaitu ketidakadekuatan perilaku memeriksakan kehamilan/kunjungan antenatal care (ANC), ketidakpatuhan mengkonsumsi tablet besi (Fe), kuatnya kebiasaan mengkonsumsi teh, ketidakadekuatan perilaku hidup bersih dan sehat (terkait dengan anemia).
\end{abstract}

Kata Kunci: Perilaku Hidup Bersih dan Sehat, Ibu Hamil, Anemia

\begin{abstract}
Background: Pregnant women who are in the household who is clean and healthy living behaviors (PHBs) will decrease the incidence of diseases that worsen maternal mortality, given the fact that pregnant women are vulnerable to the risk that requires an environment of family/household who have behavior clean and healthy (Astuti, 2011). Objective: to get an idea deeply about clean and healthy
\end{abstract}


behaviors in pregnant women with anemia in Puskesmas Imogiri I Bantul Yogyakarta. Method: This study used a qualitative research approach to the design of phenomenology. The sampling technique used purposive sampling technique. Collecting data with in-depth interviews in 6 pregnant women anemia in Puskesmas Imogiri I Bantul, Yogyakarta. This research was conducted in May to September 2014. Data analysis techniques used in this study using analytical techniques Colaizzi. Result: Four themes found in this research that the inadequate behavior during their pregnancy/antenatal care visit (ANC), noncompliance consume iron tablet $(\mathrm{Fe})$, the strength of the habit of drinking tea, and the inadequate behavior of clean and healthy life (related to anemia). Conclusion: Overview of a clean and healthy living behaviors in pregnant women with anemia in Puskesmas Imogiri I Bantul Yogyakarta can be seen from four important findings of this study are the inadequate behavior of antenatal/visit antenatal care (ANC), noncompliance consume iron tablet $(\mathrm{Fe})$, strong tea drinking habits, the inadequate behavior of healthy and clean life (related to anemia).

Keywords: Behavior Clean and Healthy Pregnancy, Anemia

\section{PENDAHULUAN}

Departemen Kesehatan telah mencanangkan Gerakan Pembangunan Berwawasan Kesehatan yang dilandasi paradigma sehat. Berdasarkan paradigma sehat ditetapkan Visi Indonesia Sehat 2010, dimana ada tiga pilar yang perlu mendapat perhatian khusus, yaitu lingkungan sehat, perilaku sehat, serta pelayanan kesehatan yang bermutu, adil dan merata. Bentuk konkrit dari perilaku sehat adalah perilaku proaktif memelihara dan meningkatkan kesehatan, mencegah risiko terjadinya penyakit, melindungi diri dari ancaman penyakit serta berpartisipasi aktif dalam upaya kesehatan. Mengingat dampak dari perilaku terhadap derajat kesehatan cukup besar, maka diperlukan berbagai upaya untuk mengubah perilaku yang tidak sehat menjadi sehat (Depkes, 2007).

Perubahan perilaku pasien, individu sehat dan keluarga (rumah tangga) akan sulit dicapai jika tidak didukung oleh sistem nilai dan normanorma sosial serta norma-norma hukum yang dapat diciptakan/dikembangkan oleh para pemuka masyarakat, baik pemuka informal maupun pemuka formal (Kemenkes, 2011). Penelitian yang dilakukan oleh Suryani, et al (2013) menunjukkan bahwa rumah tangga yang telah mempraktikkan Perilaku Hidup Bersih dan Sehat (PHBS) di Kelurahan Payo Selincah Jambi 54\%, data Riskesdas 2007 menunjukkan bahwa rumah tangga yang telah mempraktikkan PHBS $38,7 \%$, sedangkan target yang harus dicapai oleh Kementerian Kesehatan yaitu sebesar $70 \%$ rumah tangga sudah mempraktikkan PHBS pada tahun 2014 (Depkes, 2008). Berdasarkan studi pendahuluan yang dilakukan pada tanggal 6 Nopember 2013, rumah tangga yang telah mempraktikkan PHBS di wilayah Bantul 42,65\% sedangkan di wilayah kerja Puskesmas Imogiri I Bantul pada tahun 2012 
sebesar 21,31\%. PHBS di rumah tangga dilakukan untuk mencapai rumah tangga sehat.

Ibu hamil yang berada dalam rumah tangga yang melakukan PHBS akan menurunkan kejadian penyakit yang memperburuk kematian ibu hamil, mengingat bahwa ibu hamil sebenarnya merupakan kelompok yang rentan terhadap resiko sehingga memerlukan suatu lingkungan keluarga/rumah tangga yang mempunyai perilaku hidup bersih dan sehat (Astuti, 2011). Penelitian yang dilakukan Astuti (2011) menunjukkan bahwa PHBS dalam rumah tangga ibu hamil dan ibu pernah hamil ditinjau menurut provinsi, tingkat ekonomi, dan tingkat pendidikan masih sangat rendah. Perilaku ibu hamil seperti merokok atau penggunaan tembakau, penggunaan alkohol, perubahan pola diet dapat menyebabkan anemia (Lin, 2009). Perilaku tidak sehat pada ibu hamil tidak berdiri sendiri, semua adalah akibat dari penyebab mendasarnya seperti kemiskinan termasuk miskinnya pengetahuan ibu hamil dan keluarga tentang bagaimana memelihara kehamilannya sehingga muncul perilaku tidak sehat (Yogaswara, 2011).

Anemia pada kehamilan merupakan salah satu masalah nasional karena mencerminkan nilai kesejahteraan sosial ekonomi masyarakat dan pengaruhnya sangat besar terhadap kualitas sumber daya manusia. Anemia pada ibu hamil disebut "potensial danger to mother and child" (potensial membahayakan ibu dan anak). Oleh karena itu anemia memerlukan perhatian serius dari semua pihak yang terkait dalam pelayanan kesehatan (Manuaba, 2010). Anemia masih dianggap suatu kondisi yang normal dan merupakan proses alamiah yang terjadi selama kehamilan serta kepercayaan dan pantangan makanan merupakan perilaku yang dapat menyebabkan anemia kehamilan (Triratnawati, 1997; Harnany, 2006). Hasil penelitian Setyowati (2010) menunjukkan bahwa dari 40 partisipan, kurang lebih seperempatnya melakukan pembatasan makan selama hamil karena takut kalau janin yang dikandungnya menjadi besar sehingga akan sulit dalam proses melahirkan. Selain itu keluarga dan masyarakat juga berpengaruh terhadap perilaku wanita dalam pemenuhan nutrisi selama hamil.

Ibu hamil memerlukan tablet besi untuk pembentukan haemoglobin, sehingga pemerintah Indonesia mengatasinya dengan pemberian suplemen tablet besi untuk ibu hamil sejak tahun 1974 melalui program puskesmas dan posyandu. Jumlah tablet zat besi yang dikonsumsi ibu hamil minimal 90 tablet selama kehamilan (Kemenkes RI, 2011). Anemia gizi besi menjadi masalah utama bagi semua kelompok umur, dimana prevalensi yang paling tinggi pada ibu hamil sebesar 55\% (Arisman, 2010).

Menurut laporan World Health Organization (WHO) pada tahun 2008 bahwa prevalensi anemia pada ibu hamil di dunia mencapai $41,8 \%$ dengan angka tertinggi kejadian di Afrika dan Asia Tenggara, berturut-turut 57,1\% dan 48,2\%. Angka kejadian anemia ibu hamil di Indonesia mencapai $70 \%$ atau 7 dari 10 wanita hamil menderita anemia (Almatsier, 2011). Hartati (2005) menyebutkan bahwa prevalensi anemia ibu hamil di Propinsi Daerah Istimewa Yogyakarta sebesar 73,9\%. Sebagian besar anemia pada ibu hamil 
di Indonesia dinyatakan sebagai akibat kekurangan zat besi (Saifuddin, 2006). Berdasarkan studi pendahuluan yang dilakukan pada tanggal 6 Nopember 2013, prevalensi anemia ibu hamil Kabupaten Bantul tahun 2012 sebesar $31,38 \%$. Sedangkan angka kejadian anemia pada ibu hamil dari bulan April 2013 sampai dengan bulan Oktober 2013 di Puskesmas Imogiri I Bantul Yogyakarta yaitu 172 kasus dari 560 ibu hamil yang ada.

Perawat maternitas yang berperan sebagai edukator dan advokat bagi ibu hamil mempunyai tanggung jawab dalam memfasilitasi ibu hamil dan keluarga untuk mendapatkan informasi yang terkait dengan PHBS serta perawatan selama masa kehamilan termasuk kebutuhan nutrisi selama hamil. Pendidikan kesehatan selama masa kehamilan termasuk salah satu standar praktek keperawatan dan merupakan bentuk tanggung jawab perawat terhadap ibu hamil dan keluarga (Perry, 2010).

Peran perawat maternitas dalam menanggulangi kasus anemia pada ibu hamil tidak hanya mengkaji status nutrisi secara fisiologis, tetapi pengkajian secara komprehensif termasuk faktor sosial budaya di dalam masyarakat dan status nutrisi selama kehamilan (Reeder, 2011). Menurut Setyowati (2003), faktor sosial budaya sangat kuat mempengaruhi wanita hamil dalam menentukan nutrisi selama kehamilan. Oleh karena itu, untuk mencapai efektivitas dan efisiensi program penanggulangan anemia pada ibu hamil, seharusnya berorientasi pada kekhasan wilayah masing-masing (Zaluchu, 2007).

\section{BAHAN DAN METODE}

Penelitian ini menggunakan pendekatan penelitian kualitatif dengan desain fenomenologi. Teknik pengambilan sampel menggunakan teknik purposive sampling. Pengumpulan data dengan wawancara mendalam pada 6 ibu hamil anemia di wilayah kerja Puskesmas Imogiri I Bantul Yogyakarta. Penelitian ini dilakukan pada bulan Mei sampai September 2014. Alat bantu yang dipakai dalam kegiatan pengumpulan data yaitu berupa pedoman wawancara semi terstruktur yang telah disusun berdasarkan tujuan penelitian dan disusun dengan pertanyaan terbuka yang bersifat fleksibel selama proses wawancara agar informasi dari partisipan dapat diserap secara maksimal, tape recorder, dan catatan lapangan. Teknik analisis data yang digunakan dalam penelitian ini menggunakan teknik analisis Colaizzi.

\section{HASIL}

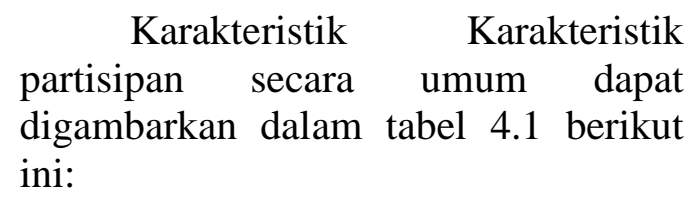

Karakteristik Karakteristik digambarkan dalam tabel 4.1 berikut 
Tabel 4.1 Karakteristik Ibu Hamil Anemia di Wilayah Kerja Puskesmas Imogiri I Bantul Yogyakarta

\begin{tabular}{ccccccc}
\hline Item & P1 & P2 & P3 & P4 & P5 & P6 \\
\hline Usia (tahun) & 19 & 28 & 29 & 30 & 32 & 19 \\
\hline Status gravida & G1P0A0 & G1P0A0 & G2P1A0 & G2P1A0 & G2P1A0 & G1P0A0 \\
\hline $\begin{array}{c}\text { Usia kehamilan } \\
\text { (minggu) }\end{array}$ & 36 & 34 & 38 & 38 & 39 & 37 \\
\hline Hb & 10 & 10,2 & 10 & 8,2 & 9,6 & 10 \\
\hline Agama & Islam & Islam & Islam & Islam & Islam & Islam \\
\hline $\begin{array}{c}\text { Pendidikan } \\
\text { terakhir }\end{array}$ & SMA & SMA & SMA & SMP & SPK & SMP \\
\hline Pekerjaan & IRT & Swasta & Swasta & IRT & IRT & Swasta \\
\hline
\end{tabular}

Berdasarkan tabel 4.1 di atas dapat diketahui bahwa semua partisipan merupakan ibu hamil trimester III dengan kadar hemoglobin kurang dari $11 \mathrm{gr} \%$. Empat tema yang muncul dari penelitian ini akan diuraikan secara rinci berikut ini:

a. Ketidakadekuatan perilaku memeriksakan kehamilan/kunjungan antenatal care (ANC).

Sebagian besar partisipan melakukan pemeriksaan kehamilan sejak trimester satu secara rutin di Puskesmas Imogiri I. Mayoritas partisipan rutin memeriksakan kehamilannya didukung adanya kesadaran yang tinggi terhadap kesehatannya. Namun demikian dalam penelitian ini didapatkan satu partisipan yang tidak rutin memeriksakan kehamilannya karena ia tidak merasa ada keluhan selama kehamilannya. Sejak merasa tubuhnya lemas, partisipan tersebut baru mulai memeriksakan kehamilannya sebagaimana diungkapkan:

“...pada saat sebelum hamil sih saya cek sendiri $\mathrm{Hb}$ saya masih bagus..12..e..saat hamil kok semakin turun...makanya saya makin lama makin merasakan lemes...terus saya baru periksa ke Puskesmas Imogiri I itu... saat usia kehamilan kurang lebih tujuh bulanan...”. (P5)

Ungkapan P5 senada dengan yang disampaikan oleh ibu P5 ketika dikonfirmasi ulang terkait kebiasaan anaknya dalam memeriksakan kehamilannya, Ia mengatakan:

“...anak kulo niku namung ngombeni madu niku mawon....nek obat sik saking puskesmas le mungal mboten sae...dados nggih mboten mriksake ten puskesmas....kaliyan le mungal ken nambahi le maem sayuuran....pangapunten...nek

kulo rak namung kulo sekarep mawon mba...si penting ibue lan bayine sehat-sehat to mba.." (anak saya itu hanya minum madu itu saja...kalau obat yang dari puskesmas katanya gak baik...jadi ya tidak memeriksakan ke puskesmas....dan katanya disuruh menambah makan sayuran...gak tahu...kalau saya hanya saya biarkan saja mba...yang penting ibu dan bayinya sehat-sehat to mba..). 
b. Ketidakpatuhan mengkonsumsi tablet besi $(\mathrm{Fe})$.

Semua partisipan mendapat vitamin dan tablet besi (Fe). Namun ada dua orang partisipan yang tidak patuh untuk minum vitamin dan tablet besi $(\mathrm{Fe})$, dengan alasan saat mengkonsumsi tablet besi ( $\mathrm{Fe})$ timbul adanya reaksi mual dan muntah. Seperti yang diungkapkan partisipan ketika ditanya terkait konsumsi tablet besi sebagai berikut:

"pernah yang dari puskesmas minum 3 kali, tapi setiap habis minum mesti mual..makanya terus balik lagi, tapi kalau minum obimin gak mual...tapi ya tidak rutin, soalnya saya gak punya keluhan apa-apa". (P4)

Ungkapan P4 senada dengan yang disampaikan oleh ibu P4 ketika dikonfirmasi ulang terkait kebiasaan anaknya minum tablet besi dari puskesmas, Ia mengatakan:

“...Nggih niku kit mbobot pertama niku awis awis purun ngombe pil penambah darah...le mungal mulek-mulek ngoten je bu... (...ya itu sejak hamil pertama jarang mau minum tablet penambah darah...katanya mual-mual bu...").

Alasan lain yang disampaikan P5 adalah karena keinginannya untuk mengkonsumsi zat besi secara alami dan adanya informasi bahwa tablet $\mathrm{Fe}$ mengandung unsur babi, sebagaimana ungkapan partisipan sebagai berikut:

"...he he...tapi memang saya gak minum tablet penambah darah, saya itu pinginnya yang alami alami saja...menambah mengkonsumsi sayuran, tahu, tempe, ikan...kalau sama pasien saya menganjurkan untuk minum penambah darah..tapi saya sendiri gak minum...soalnya katanya bungkusnya itu...gelantinnya mengandung babi...jadi saya gak minum...saya ganti dengan sari kurma dan madu katanya juga cepet untuk menaikkan $\mathrm{Hb}$...tapi akhirnya saya juga periksa ke Puskesmas Imogiri I lagi...di kasih penambah darah lagi..tapi saya minum yang kaplet bukan kapsul...dosisnya dinaikkan sehari 3 kali karena mendekati melahirkan...". (P5)

c. Kuatnya kebiasaan mengkonsumsi teh.

Temuan lain dari hasil penelitian ini adalah bahwa tiga dari enam partisipan ibu hamil anemia rutin/suka mengkonsumsi teh sebelum dan sesudah makan bahkan pada saat minum tablet besi. Alasan utama yang disampaikan oleh partisipan adalah tidak puas kalau tidak minum teh. Seperti yang diungkapkan salah satu partisipan berikut ketika ditanya terkait dengan kebiasaan minum teh sebagai berikut:

"Kalau minum teh saya suka banget mba...keluarga saya ya..ibu...bapak suka buat teh panas, manis...kalau gak minum teh rasanya gimana gitu...rasanya seperti belum kemepyar". (P1)

Hal senada juga disampaikan oleh ibu P1, saat ditanya apakah P1 sering minum teh, Ia mengatakan:

“...wah ngunjuk teh niku pun dadi kebiasaan keluargo kit riyin...menawi dereng ngeteh niku raosi badan niku kados tesih lemes.......wah minum teh itu sudah jadi kebiasaan keuarga dari dulu...kalau belum minum teh itu rasanya seperti tubuh masih lemas...)". 
d. Ketidakadekuatan Perilaku Hidup Bersih dan Sehat (terkait dengan anemia).

Beberapa sub tema yang membentuk tema ketidakadekuatan perilaku hidup bersih dan sehat (terkait dengan anemia) terdiri atas: perilaku mencuci tangan tidak adekuat, perilaku makan sehari-hari tidak adekuat, perilaku mengkonsumsi sayur dan buah tidak adekuat, perilaku aktivitas fisik/olahraga tidak adekuat, dan kebutuhan istirahat kurang terpenuhi tidak adekuat.

Mayoritas partisipan mempunyai kebiasaan mencuci tangan pada saat sebelum dan sesudah makan, setelah buang air besar. Namun tidak setiap mencuci tangan menggunakan sabun, partisipan menggunakan sabun kalau setelah buang air besar saja, sebelum dan sesudah makan rata-rata tidak menggunakan sabun. Sebagaimana yang diungkapkan partisipan pada saat ditanya tentang kebiasaan mencuci tangan sebagai berikut:

"ya saya cuci tangan sebelum makan, sesudah makan.terus kalau sesudah buang air besar..kalau habis mbathik...pakai sabunnya kalau habis buang air besar dan habis mbathik kan untuk menghilangkan baunya...kalau mau makan dan sesudah makan tidak mesti pakai sabun, paling kalau habis makan ikan biar gak bau amis" (P3)

Kebiasaan makan dan menu makanan partisipan sehari-hari cenderung tidak berbeda dengan menu makanan sebelum hamil. Beberapa partisipan menyatakan frekuensi makan dalam sehari sekitar 2-4 kali/hari, dengan porsi kecil dan ada yang menyatakan malas makan dan diganti dengan makanan ringan sebagaimana diungkapkan partisipan berikut ini:

"kadang-kadang memeng maem (dalam Bahasa Indonesia berarti malas makan) bu, pinginnya ngemil..biasanya roti kemasan niko lo..ya kayak-kayak gitu..rotiroti kering". (P2)

"...tapi ya saya tetap makan mi..kadang-kadang nyolongnyolong lah mba..."(P6)

Pernyataan P6 senada dengan pernyataan yang disampaikan oleh ibu P6 sebagai berikut:

"lha wong hamil kok senenge maem mi terus....niko lho mi..sebongso mi rebus..mi goreng....ge le damel mi mboten dicampuri sayur...nopo bayem, nopo sawi...mboten purun sayur..dadi ten awak yo mboten seger...(dalam Bahasa Indonesia "Orang hamil kok sukanya makan mi terus, itu lho...seperti mi rebus...mi goring..terus memasak mi nya tidak dicampur dengan saur seperti bayem atau sawi...tidak mau sayur...jadi di tubuh ya tidak segar...)".

Pola konsumsi partisipan lebih banyak mengkonsumsi sumber nabati daripada hewani. Selain itu konsumsi dari jenis makanan terlihat kurang bervariasi antara sayuran, ikan, ayam, daging, maupun buah-buahan.

Realitas ini terlihat dari ungkapan partisipan yang menyatakan bahwa lauk pauk yang dikonsumsi sehari-hari lebih banyak dari sayuran hijau, tahu, tempe yang memiliki daya serap zat besi rendah. Untuk jenis makanan dengan daya serap zat besi tinggi seperti ikan, ayam dan daging jarang dikonsumsi. Hal ini seperti yang disampaikan oleh 
partisipan pada saat ditanya tentang jenis/menu makanan sehari-hari sebagai berikut:

"kalau saya sih seadanya bu, ada tempe ya makan tempe, ada tahu ya makan tahu..asalkan tidak yang pahit, saya gak suka... ya mau, tapi kalau sering ya jeleh bu, (...telur, daging, ikan)". (P1)

Sebagian besar partisipan mengkonsumsi sayur setiap hari, sebagaimana diungkapkan oleh partisipan ketika ditanya tentang kebiasaan makan sayur sebagai berikut:

"kalau makan ya ada sayurnya...hampir mesti... kalau sayur itu ya...setiap hari.. ...itu lho sayur bening...sop..bayem..atau apa itu..soalnya anak saya yang pertama kalau gak ada sayurnya gak mau makan..jadi setiap hari bikin sayur..." (P3)

Tetapi ada juga partisipan yang kurang mengkonsumsi sayur, sebagaimana diungkapkan sebagai berikut:

“...kurang makan sayur-sayuran, kan saya suka mie instan tapi gak saya campur dengan sayuran...". (P6)

Mayoritas partisipan tidak melakukan aktifitas fisik/olahraga secara teratur, seperti yang diungkapkan oleh salah satu partisipan sebagai berikut:

“...kalau olahraga rutin sih gak bu...paling kalau pagi naik sepeda ngantar anak saya sekolah...terus siang jemput anak sekolah...terus mbathik...". (P3)

Sebagian besar kebutuhan istirahat partisipan terpenuhi, tetapi dua partisipan ibu hamil anemia dalam penelitian ini mengungkapkan kebutuhan istirahatnya kurang terpenuhi sebagaimana ungkapan partisipan pada saat ditanya tentang kebutuhan istirahat tidur sebagai berikut:

“..tapi gini lho bu...saya sering tidur malam...nunggu suami pulang kerja...kadang sampai jam sebelas malam...habis itu kan masih ngladeni suami juga to bu...". (P1)

“...tapi tidur saya kurang mba...nunggu ibu saya to itu...di rumah...kan sesek itu..gak bisa tidur to.. cuma saya..gak ada yang ganti kan kalau malam...saya terus...kalau siang bikin makan di rumah sini...terus malam ke ibu...kalau sore dari sini sampai sana jalan...terus naik..paginya pulang ke sini ngurusin anak sekolah...nanti jemput anak sekolah...nanti habis jemput membathik...terus sorenya ke sana lagi...malam gak tidur kan..nahan ngantuk...saya kira cuma itu yang bikin Hb saya ngedrop...capek...”. (P3)

\section{PEMBAHASAN}

Empat temuan penting dalam penelitian Perilaku Hidup Bersih dan Sehat pada Ibu Hamil dengan Anemia di Wilayah Kerja Puskesmas Imogiri I Kabupaten Bantul Yogyakarta yaitu ketidakadekuatan perilaku memeriksakan kehamilan/kunjungan antenatal care (ANC), adanya pertentangan

keyakinan/ketidakpercayaan tentang kandungan tablet besi (Fe), kuatnya budaya minum teh pada ibu hamil, dan perilaku hidup bersih dan sehat pada ibu hamil tidak adekuat. Temuan tersebut akan diuraikan lebih rinci dalam pembahasan sebagai berikut: 
1. Ketidakadekuatan perilaku memeriksakan kehamilan/kunjungan antenatal (ANC)

Pemeriksaan antenatal care yang lengkap diharapkan ibu hamil mendapat pelayanan yang lebih baik khususnya yang berkaitan dengan upaya pencegahan anemia seperti pemberian tablet besi dan penyuluhan gizi ibu hamil sehingga kejadian anemia ibu hamil semakin berkurang. Setiap ibu hamil menghadapi risiko terjadinya komplikasi, oleh karena itu setiap wanita hamil diharapkan sedikitnya satu kali memeriksakan kehamilannya, bahkan diharapkan 4 kali memeriksakan diri selama masa kehamilan (Depkes, 2007). Ibu hamil disarankan memeriksakan kehamilan dalam waktu kehamilan trimester pertama (14 minggu) satu kali kunjungan, dan kehamilan trimester kedua (14-28 minggu) satu kali kunjungan, dan trimester ketiga (28-36 minggu dan sesudah minggu ke 36) dua kali kunjungan (Salmah, 2006). Frekuensi pemeriksaan tersebut sudah memenuhi standar yang ditetapkan oleh pemerintah yaitu minimal 1 kali pada trimester 1, 1 kali pada trimester 2, dan 2 kali pada trimester 3 .

2. Pertentangan

keyakinan/ketidakpercayaan tentang kandungan tablet besi $(\mathrm{Fe})$

Kepercayaan berasal dari kata percaya, artinya mengakui atau meyakini kebenaran. Kepercayaan adalah hal-hal yang berhubungan dengan pengakuan atau keyakinan akan kebenaran (Ramawati, 2008). Secara umum manusia sebagai makhluk sosial, ibu hamil khususnya akan menanggapi dan memberikan pandangan tentang makanan yang akan dikonsumsi berdasarkan keyakinan yang dimilikinya. Secara psikologis faktor keyakinan berperan besar dalam menentukan tindakan yang akan dilakukan. Keyakinan tentang kehamilan yang dimiliki oleh masyarakat sangat menentukan perilaku masyarakat terhadap kehamilan tersebut (Notoatmodjo, 2003) Pengaruh keyakinan merupakan salah satu faktor yang mendasari ketidakpatuhan dalam melakukan antenatal care dan dalam mengkonsumsi tablet besi (Fe) selama kehamilan. Kepercayaan dapat diperoleh dari orang tua, suami, kakek atau nenek. Sering seseorang menerima kepercayaan itu berdasarkan keyakinan saja tanpa adanya pembuktian terlebih dahulu (Puspasari, 2008). Begitu pula dengan ibu hamil ketika dirinya benar-benar percaya bahwa tablet besi mengandung unsur babi yang dilarang untuk dikonsumsi sesuai dengan agama yang dianutnya maka ibu hamil tersebut tidak mengkonsumsi tablet besi. Hal ini sejalan dengan penelitian yang dilakukan oleh Puspasari (2008) dan Ramawati (2008) menunjukkan bahwa kepercayaan merupakan salah satu faktor yang mempengaruhi kepatuhan ibu hamil dalam mengkonsumsi tablet besi.

3. Kuatnya budaya minum teh pada ibu hamil

Menurut data Head of Researcher Brand Research, teh merupakan salah satu minuman yang paling populer di dunia. Kebiasaan minum teh sudah menjadi budaya bagi penduduk dunia. Selain air putih, teh merupakan minuman 
yang paling banyak dikonsumsi oleh manusia. Rata-rata konsumsi teh penduduk dunia adalah 120 $\mathrm{ml} /$ hari/kapita. Indonesia merupakan negara penghasil teh terbesar keenam di dunia dengan tingkat konsumsi teh orang Indonesia mencapai $0.8 \quad \mathrm{~kg} / \mathrm{tahun} / \mathrm{kapita}$ (Machmud, 2006).

Minum teh sudah menjadi budaya di keseharian masyarakat Indonesia khususnya dan masyarakat Asia pada umumnya. Hampir setiap rumah menyimpan teh sebagai salah satu minuman favoritnya. Orang Indonesia terbiasa mengkonsumsi teh setelah makan. Bahkan ada kelompok masyarakat tertentu yang mengkonsumsi teh kental setiap hari (Bambang, 2008).

Teh adalah minuman yang kaya antioksidan. Cao et al. (1996) menemukan bahwa teh hijau dan teh hitam mempunyai kadar antioksidan yang lebih tinggi dibandingkan dengan sayuran seperti bawang putih, dan bayam. Teh diketahui mempunyai manfaat terhadap kesehatan antara lain menghambat perkembangan kanker (Yang $\mathrm{C}$ et al, 2000), menurunkan risiko terjadinya penyakit kardiovaskuler (Hertog, 1997), menjaga kesehatan gigi dan mulut karena kandungan natural florida dapat mencegah karies pada gigi (Jones $\mathrm{C}$ et al, 1999). Hindmarch et al (2000) melaporkan bahwa teh dapat meningkatkan kondisi kognitif dan psikomotor pada orang dewasa. Hegarty et al (2000) juga melaporkan bahwa teh dapat mengurangi risiko terjadinya patah tulang pada usila karena densitas tulang pada mereka yang minum teh lebih baik daripada mereka yang tidak minum teh.
Walaupun teh mempunyai manfaat bagi kesehatan, namun ternyata teh juga diketahui menghambat penyerapan zat besi yang bersumber dari bukan hem (non-heme iron) (Soehardi, 2004). Hurrell et al (1999) melaporkan bahwa teh dapat menghambat penyerapan zat besi non-heme sebesar 79-94\% jika dikonsumsi bersama-sama. Beberapa penelitian menemukan bahwa ada hubungan antara minum teh dengan kejadian anemia (Neifani, 2009; Novita, 2011; Bangun, 2012). Hal ini sejalan dengan hasil penelitian Besral et al (2007), bahwa memperlihatkan hubungan antara kebiasaan minum teh dengan kejadian anemia. Dari hasil penelitian terlihat bahwa proporsi kejadian anemia lebih tinggi pada kelompok yang selalu minum teh setiap hari (83\%) dibandingkan dengan kelompok yang hanya kadang-kadang atau tidak pernah minum teh (kejadian anemianya hanya $15 \%$ dan $11 \%$ ), dari nilai odds ratio terlihat bahwa risiko kelompok yang minum teh tiap hari untuk menderita anemia adalah 36 kali lebih besar dibandingkan kelompok yang tidak pernah minum teh. Pada kelompok yang kadang-kadang minum teh kejadian anemianya tidak berbeda bermakna dengan kelompok yang tidak pernah minum teh.

Penelitian ini membuktikan bahwa faktor yang berperan dalam kejadian anemia adalah perilaku minum teh setiap hari. Walaupun telah banyak penelitian yang membuktikan beragam manfaat dari minum teh, namun cara konsumsi teh yang tidak tepat akan menimbulkan dampak negatif, 
terutama terjadinya anemia. Hal ini dapat disebabkan oleh beberapa hal antara lain karena teh mengandung tanin yang dapat mengikat mineral (termasuk zat besi) dan pada sebagian teh (terutama teh hitam) senyawa polifenol yang berperan sebagai antioksidan ternyata telah mengalami oksidasi, sehingga dapat mengikat mineral seperti $\mathrm{Fe}, \mathrm{Zn}$, dan Ca sehingga penyerapan zat besi berkurang, sedangkan pada teh hijau senyawa polifenolnya masih banyak, sehingga masih dapat meningkatkan peranannya sebagai antioksidan (Besral et al, 2007).

4. Perilaku hidup bersih dan sehat pada ibu hamil tidak adekuat

Ibu hamil membutuhkan makanan yang bergizi, baik untuk dirinya sendiri maupun untuk memenuhi kandungan nutrisi bagi janin yang dikandungnya. Selama trimester I kehamilan, kebutuhan zat besi ibu lebih rendah karena tidak menstruasi dan zat besi yang digunakan janin minimal. Mulai dari trimester II terdapat pertambahan sel-sel darah merah yang berlangsung sampai trimester III. Penambahan sel-sel darah merah tersebut kira-kira sama dengan penambahan sebesar $450 \mathrm{mg}$ besi. Selama kehamilan tubuh wanita memerlukan $\pm 1000 \mathrm{mg} \mathrm{Fe}$. Kebutuhan $\mathrm{Fe}$ digunakan untuk perkembangan janin $300 \mathrm{mg}$, plasenta $50 \mathrm{mg}$, ekspansi sel darah merah, kehilangan basal $240 \mathrm{mg}$. Distribusi kebutuhan $\mathrm{Fe}$ ini tidak sama dari waktu ke waktu selama kehamilan. Kebutuhan $\mathrm{Fe}$ ini terutama meningkat pada trimester terakhir. Pada awal kehamilan kebutuhan $\mathrm{Fe}$ pada wanita adalah 0,8 $\mathrm{mg} / \mathrm{hari}$, kebutuhan terus meningkat hingga mencapai 10-12 mg/hari pada akhir kehamilan (Husaini, 1989).

Protein hewani dan protein nabati merupakan suatu zat yang sangat penting bagi tubuh karena merupakan sumber protein dan berfungsi sebagai bahan bakar dalam tubuh dan sebagai zat pembangun. Fungsi protein adalah menggantikan sel yang rusak. Kekurangragaman menu dan jumlah makanan dalam konsumsi seharihari cukup memberi pengaruh pada keadaan gizi seseorang dan juga status anemia (Harnany, 2006).

Melakukan pekerjaan yang berat di saat hamil memang menjadi salah satu penyebab dari berkurangnya kemampuan tubuh dalam memenuhi kebutuhan ibu dan janin yang dikandungnya. Kebutuhan nutrisi misalnya zat besi, terkuras habis cadangannya untuk memenuhi aktivitas ibu hamil Akibatnya, seorang ibu hamil bisa mengalami yang disebut sebagai anemia dalam kehamilan (Cunningham dkk, 2006). Kurangnya tidur setelah shif malam pada buruh pabrik juga akan mempengaruhi kadar haemoglobin. Berkurangnya waktu tidur, berarti semakin meningkatkan penggunaan energi. Dengan demikian penggunaan energi ini perlu diimbangi dengan input makanan yang memadai untuk pembentukan energi kembali yang digunakan untuk biosintesis dan reparasi sel-sel tubuh yang mengalami kerusakan (Haribi, 2004). 


\section{SIMPULAN DAN SARAN \\ Simpulan}

Gambaran tentang perilaku hidup bersih dan sehat pada ibu hamil dengan anemia di wilayah kerja Puskesmas Imogiri I Kabupaten Bantul Yogyakarta dapat dilihat dari empat temuan penting dari penelitian ini yaitu ketidakadekuatan perilaku memeriksakan kehamilan/kunjungan antenatal care (ANC), ketidakpatuhan mengkonsumsi tablet besi (Fe), kuatnya kebiasaan mengkonsumsi teh, ketidakadekuatan perilaku hidup bersih dan sehat (terkait dengan anemia).

\section{Saran}

1. Bagi petugas kesehatan di ruang periksa Kesehatan Ibu dan Anak (KIA) Puskesmas Imogiri I Bantul Yogyakarta

Perlunya promosi tentang Perilaku Hidup Bersih dan Sehat pada ibu hamil lebih ditingkatkan dan metode untuk promosi tentang Perilaku Hidup Bersih dan Sehat sebaiknya disesuaikan dengan kemampuan ibu hamil, sehingga mereka mengerti betul apa yang dimaksud dengan Perilaku Hidup Bersih dan Sehat dan apa yang harus mereka lakukan. Selain itu, ibu hamil perlu dimotivasi agar mereka mau dan mampu melakukan Perilaku Hidup Bersih dan Sehat dengan benar.

2. Bagi penelitian selanjutnya

a. Penelitian kuantitatif.

Penelitian ini dapat dijadikan referensi untuk penelitian selanjutnya, yaitu tentang persepsi tenaga kesehatan terhadap pemberian tablet besi (Fe) pada ibu hamil dengan anemia. b. Penelitian kualitatif.

Penelitian ini dapat dilanjutkan dengan mengeksplorasi lebih dalam terkait peran keluarga dalam perilaku hidup bersih dan sehat ibu hamil dengan anemia.

\section{DAFTAR PUSTAKA}

Almatsier, Sunita., Soetardjo, Susirah., Soekatri, Moesijanti., 2011. Gizi Seimbang Dalam Daur Kehidupan. PT Gramedia Pustaka Utama. Jakarta

Arisman. 2010. Buku Ajar Ilmu Gizi: Gizi dalam Daur Kehidupan (edisi 2). EGC. Jakarta

Astuti, WD., Khaqiqi, Z., Lestari, D., 2011. Perilaku Hidup Bersih dan Sehat (PHBS) dalam Rumah Tangga Ibu Hamil dan Ibu Pernah Hamil Di Indonesia. Pusat Humaniora, Kebijakan Kesehatan dan Pemberdayaan Masyarakat, Badan Penelitian dan Pengembangan Kesehatan.

Bambang, K. 2008. Prospek Teh Indonesia Sebagai Minuman Fungsional. Diunduh dari http:scribd.com pada tanggal 18 Desember 2014

Bangun, E. B., Lubis, Z., Siagian, A. 2012. Perilaku Minum Teh dan Kadar Hemoglobin ( $\mathrm{Hb})$ pada Siswa Siswi Sekolah Menengah Kejuruan Negeri 1 Jorlang Hataran Desa Dolok Marlawan Kecamatan Jorlang Kabupaten Simalungun. Penelitian Fakultas Kesehatan Masyarakat.

Besral, Meilianingsih, L., Sahar, J., 2007. Pengaruh Minum Teh Terhadap Kejadian Anemia Pada Usila Di Kota Bandung. Journal Makara Kesehatan. Vol. 11. No 1. Juni 2007: 38-43 
Cao G, Sofic E, Prior R. 1996. Antioxidant Capacity of Tea and Common Vegetables. Journal of Agree Food Chem. 1999 (44):34263431

Cunningham, FG, Paul C MacDonald, dan Norman F Gant. 2006. Obstetri Williams Edisi 18. Alih bahasa Joko Suyono dan Andry Hartono, EGC, Jakarta

Daud R. 2000. Hubungan Antara Tingkat Pendidikan, Pendapatan, dan Perilaku Masyarakat dengan Kualitas Sanitasi Lingkungan. Tesis Pascasarjana IKM UGM. Yogyakarta

Departemen Kesehatan RI. 2002. Penyuluhan Kesehatan Masyarakat. Pusat Promosi Kesehatan Departemen Kesehatan RI. Jakarta

2004. Pencegahan dan

Penanggulangan Penyakit Demam Berdarah Dengue, World Health Organization dan Departemen Kesehatan RI. Jakarta 2007. Buku Saku Rumah Tangga Sehat dengan PHBS. Pusat Promosi Kesehatan. Jakarta . 2008. Riset Kesehatan

Dasar 2007. Badan Penelitian dan Pengembangan Kesehatan

Edwards, dkk. 2010. Praktik Kebidanan: Kesehatan Masyarakat. Jakarta: EGC

Haribi, Ratih. 2004. Kadar Haemoglobin Pada Buruh Wanita Yang Bekerja Di Malam Hari. Dalam Jurnal Litbang Universitas Muhammadiyah Semarang. Vol. 1.No1 Sep. 2004. Semarang

Harnany, A.S. 2006. Pengaruh Tabu Makanan, Tingkat Kecukupan Gizi, Konsumsi Tablet Besi, Dan Teh Terhadap Kadar Hemoglobin Pada
Ibu Hamil di Kota Pekalongan Tahun 2006. Tesis. Magister Gizi Masyarakat Program Pasca Sarjana Universitas Diponegoro diambil dari

http://eprints.undip.ac.id/15216/1/A fiyah_Sri_Harnany.pdf. Diakses pada tanggal 07 Februari 2015

Hartati, S. 2005. Prevalensi Anemia di DIY Sangat Tinggi (online) http://ebookbrowsee.net/gdoc.php?i d diakses tanggal 19 Desember 2013

Hegarty, V., May, H., Khaw, K. 2000. Tea Drinking and Bone Mineral Density in Older Women. American Journal of Clinical Nutrition. 2000(71):1003-1007

Hertog, M., Feskens, E., Krombout, D., 1997. Antioksidant Flavonoid and Coronary Heart Disease Risk. Lancet. 1997:349

Hindmarch, I., Rigney, U., Stanley, N., Quinlan, P., Rycroft, J., Lane, J. 2000. A Naturalistic Investigation of The Effects of Day-Long Consumption of Tea, Coffee an Water on Alertness, Sleep Onset and Sleep Quality. Psychopharmacology. 2000 (149):2003-2016

Hurrell RF, Reddy M, Cook JD. Inhibition of Non Haem Iron Absorption in Man by Polyphenolic-Containing Beverages. British Journal of Nutrition. 1999 (81):289-295

Husaini. 1989. Study Nutritional Anemias an Assesment of Information Complation for Supporting and Formulating National Policy and Programe. Directorate of Community Nutrition and Center for Nutrition Research and Development Ministry of Health, Jakarta 
Jones, C., Woods, K., Whittle, G., Worthington, H., Taylor, G., 1999. Sugar, Drinks, Deprivation and Dental Caries in 14-Year-Old Children in The North West of England. Community Dental Health (16):68-71

Kementerian Kesehatan RI. 2011. Pedoman Pembinaan Perilaku Hidup Bersih dan Sehat (PHBS). Peraturan Menteri Kesehatan Republik Indonesia Nomor: 2269/Menkes/Per/XI/2011 Jakarta 2011. Promosi Kesehatan di Daerah Bermasalah Kesehatan. Pusat Promosi Kesehatan

Lin, Y.H., Tsai, E.M., Chan, T.F., Chou, F.H., Lin, Y.L., 2009. Health Promoting Lifestyles and Related Factors in Pregnant Women. Chang Gung Med J Vol. 32 No. 6

Linda. 2011. Janin Yang Terpapar Nikotin. Diakses dari http://www.mediasari.com/2011/07 /ancaman-rokok-bagi-wanita hamil.html. dibuka tanggal 20 Oktober 2014

Machmud, I. 2006. Cerita Tentang Teh di Indonesia: Peluang Terbuka Luas. Diunduh dari http:/www.rsi.sg/Indonesian/ruang bisnis/html diakses 18 Desember 2014.

Manuaba, I.B.G. 2010. Pengantar Kuliah Obstetri. Jakarta:EGC

Masli J, Suwarni A, Suharman. 2010. Tingkat Partisipasi Masyarakat Dalam Pengadaan Jamban Keluarga Melalui Community Lead Total Sanitation. Berita Kedokteran Masyarakat, Vol. 26, No. 3, September 2010

Moeljoharjo D. 1996. Hubungan Perilaku Penduduk Terhadap Pencemaran Bakteriologis Air Sungai Winongo di Kotamadia
Yogyakarta. Jurnal Manusia dan Lingkungan. III(9):67-79

Neifani, A., 2009. Hubungan antara Kebiasaan Minum Teh dan Asupan Zat Besi dengan Kejadian Anemia pada Laki-Laki Usia 30-34 Tahun di Kecamatan Warungasem Kabupaten Batang. Tesis Universitas Negeri Semarang. Tidak dipublikasikan

Notoatmodjo, S. 2003. Ilmu Kesehatan Masyarakat. Jakarta: PT Rineka Cipta

Novita, W., 2011. Hubungan antara Kebiasaan Minum Teh dan Asupan Tablet Zat Besi Dengan Kejadian Anemia Pada Ibu Hamil Trimester 3 Di Puskesmas Ciputat Kota Tangerang Selatan Banten. Skripsi

Perry, S.E., Hockenberry., Lowdermilk., \& Wilson. 2010. Maternal Child Nursing Care. $4^{\text {th }}$ Edition. Vol. 1. St. Louis. Mosby Elsevier

Puspasari, F. D., Saryono, Ramawati, D., 2008. Faktor-Faktor Yang Mempengaruhi Kepatuhan Ibu Hamil Dalam Mengkonsumsi Tablet Besi Di Desa Sokaraja Tengah Kecamatan Sokaraja Kabupaten Banyumas. Jurnal Keperawatan Sudirman (The Soedirman Journal of Nursing), Volume 3 No 1 Maret 2008.

Ramawati, D., Mursiyam, Sejati, W., 2008. Faktor-Faktor Yang Mempengaruhi Kepatuhan Ibu Hamil Dalam Mengkonsumsi Tablet Besi Di Desa Sokaraja Tengah Kecamatan Sokaraja Kabupaten Banyumas. Jurnal Keperawatan Sudirman (The Soedirman Journal of Nursing), Volume 3 No 3 Nopember 2008.

Reeder, S.J., Martin, L.L., Griffin, D.K. 2011. Keperawatan Maternitas Kesehatan Wanita, Bayi \& 
Keluarga. Edisi 18. Terjemahan Oleh: Yati Afiyanti, Imami Nur Rachmawati, \& Sri Djuwitaningsih. Jakarta. EGC

Ross, S. 2006. Birth Right. Jakarta: Trans Media

Saifuddin, A.B. et al. 2006. Buku Acuan Nasional Pelayanan Kesehatan Maternal dan Neonatal. Yayasan Bina Pustaka Sarwono Prawirohardjo

Setyowati. 2003. The Impact of Village Midwives and Cadres in Improving the Nutritional of Pregnant Women in Selected Rural Villages in Two Districts, Banten province Indonesia 2003: A Longitudinal Descriptive Study. Dissertation

Setyowati. 2010. An Ethnography Study of Nutritional Conditions of Pregnant Women in Banten Indonesia.Makara, Kesehatan Vol. 14, No. 1: 5-10

Soehardi, S. 2004. Memelihara Kesehatan Jasmani Melalui Makanan. ITB. Bandung

Suryani, L., Syah, S., Azim, M.M., 2013. Hubungan Pengetahuan dan Sikap Ibu Rumah Tangga Terhadap Perilaku Hidup Bersih dan Sehat di Kelurahan Payo Selincah Tahun 2013. The Jambi Medical Journal Vol 1. No 1 (2013) diambil dari http://online

journal.unja.ac.id/index.php/kedokt eran/article/view/979 diakses pada tanggal 6 Februari 2015

Triratnawati, A., 1997. Socio-Cultural Dimensions of Anemia Among Pregnant Women in Rural Areas of Java, Indonesia. Mahidol Univercity

Yang, C., Chung, Y., Yang, G., Chabra, S., Lee, M., Tea and Tea Polyphenols in Cancer Prevention.
Journal of Nutrition. 2000 (130):472S-478S

Yogaswara, D. 2011. Analisis Situasi Perilaku Sehat Ibu Hamil di Desa Sukaratu Kecamatan Sukaratu Kabupaten Tasikmalaya. FKMUNSIL.ISBN 978-602-96943-1-4

Zaluchu, F. 2007. Faktor SosioPsikologi Masyarakat yang Berhubungan dengan Anemia Ibu Hamil di Kota Tanjung Balai, Sumatera Utara. Medan: Badan Penelitian dan Pengembangan Provinsi Sumatera Utara. 